\title{
Techniques of massive data capture: A comparative approach for the assessment of complex spaces in architectural heritage
}

\author{
Técnicas de captura masiva de datos: Estudio comparativo para el análisis de espacios complejos \\ en patrimonio arquitectónico.
}

\author{
Josep Lluis i Ginovart (Main Author) \\ Universitat Rovira i Virgili, ETSA Campus Bellissens, \\ josep.lluis@urv.cat
}

Agustí Costa-Jover (Corresponding Author)

Universitat Rovira i Virgili, ETSA Campus Bellissens, Reus;

C/Universitat 1, 43204 Reus, Spain / Telf: +34 977779913

agusti.costa@urv.cat

\section{Sergio Coll-Plà}

Universitat Rovira i Virgili, ETSA Campus Bellissens,

sergio.coll@urv.cat

\section{Josep M. Puche-Fontanilles}

Institut Català d'Arqueologia Clàssica ICAC,

jpuche@icac.cat

\begin{abstract}
Planimetric documentation is a fundamental tool for the conservation of architectonic heritage. New survey techniques that are based on the massive capture of data achieve noticeable reductions in time and resources. This article discusses the implementation of these survey techniques in a complex interior space: the apse of the Tortosa Cathedral (1374-1441). The aim of this investigation was to evaluate the Terrestrial Laser Scanner (TLS) and Close Range Photogrammetry (CRP) techniques for optimizing the workflow of a complete survey of the Cathedral. This broad perspective comparison considers various factors such as precision and the used resources. This will allow the best data capture technique for each situation to be suitably established.
\end{abstract}

Keywords: Terrestrial Laser Scanner; Close Range Photogrammetry; heritage; Cathedral of Tortosa.

\begin{abstract}
Resumen
La documentación planimétrica es una herramienta fundamental en la conservación del patrimonio arquitectónico. Las nuevas técnicas de levantamiento, basadas en la captura masiva de datos permiten en la actualidad reducir notablemente el tiempo y recursos necesarios. El artículo plantea la implementación de éstas técnicas en el levantamiento de un espacio interior complejo, como es el ábside gótico de la Catedral de Tortosa (1374-1441). El objetivo de la investigación es testear las técnicas Terrestrial Laser Scanner (TLS) y Close Range Photogrammetry (CRP) para optimizar el flujo de trabajo en vistas a realizar un levantamiento completo de la Catedral. La comparativa se plantea de forma amplia, considerando diversos factores como la precisión y los recursos empleados. Esto permitirá establecer la operativa más adecuada para cada situación.
\end{abstract}

Palabras clave: Escáner Láser Terrestre; Close Range Photogrammetry; patrimonio; Catedral de Tortosa.

\section{Introduction}

The Venice Charter (UNESCO, 1964) and the 'Convention concerning the protection of the world cultural and natural heritage' (UNESCO, 1972) establish the contemporary principles for the valuation and protection of cultural and natural heritage. In addition, the ICOMOS Charter (UNESCO, 2003) defines the 'Principles for the Analysis, Conservation, and Structural Restoration of Architectural heritage', which require an exhaustive awareness about the structure to be analysed.

In this context, the topographic documentation of the architectural heritage is a fundamental tool. Current procedures allow the geometry of a building to be documented with high precision (Morán Proaño, M., Álvarez Rodríguez, 2012), (Al-kheder, Alshawabkeh, \& Haala, 2009), and it is possible to detect and monitor degradation processes. This allows a determination of the adequacy of maintenance strategies (Núñez, Buill, Regot, \& De Mesa, 2012) and enhances the historical knowledge about the analysed element. 
The use of techniques that allow the massive capture of geometrical data, such as Terrestrial Laser-Scanner (TLS) and Digital Photogrammetry, have become widespread in the assessment of built heritage (Pavlidis, Koutsoudis, Fotis, Vassilios, \& Christodoulos, 2007). They are especially useful for historical constructions, where the architecture is complex and irregular and many elements, such as vaults and domes, are not accessible. Thus, these techniques allow rapid and high accuracy indirect measurements.

The paper compares two of these techniques used in the assessment of a complex interior space, the apse of the Gothic Cathedral of Santa Maria of Tortosa (1374-1441) (Almuni, 2007). Thus, the TLS and Close Range Photogrammetry (CRP) techniques are compared. Although they are already commonly used in heritage, their use sets out specific challenges, and the technical solutions must be adapted to the complexity of the analysed space. The results will allow the optimization of these complex processes for an overall survey of the cathedral.

Description of the problem

The existing representations of the Tortosa Cathedral are relatively recent. In the cathedral's Master Plan Plan Director Sancta Maria Dertosae (Lluis i Ginovart \& Llorca, 2000), there is a detailed recompilation of the existing documents. All of the drawings were made using manual techniques with limited precision and detail.

The first computerized topography of Tortosa Cathedral was performed between 1995 and 2000 for the aforementioned Master Plan. The data capture for the survey was conducted using direct measurements that were referenced to polygonal points fixed by a total station. The numerical data were stored using CAD applications, which enabled a survey with an error of approximately 3 $\mathrm{cm}$. The representation of the floor plan has a precision that could hardly be improved with available techniques, but in the case of the vaulted ceiling a detailed survey was impossible owing to technical and resource limitations.

The evolution in techniques encouraged a new academic survey of the apse vaults in 2012 (Lluis i Ginovart, Toldrà, Costa, \& Coll, 2014). Using CRP, an unprecedented survey was conducted. However, the survey encountered limitations due to the lighting conditions and the complexity of the architecture, and the 3D model that was obtained was limited to the vaulted ceilings. Therefore, in 2013 a new survey was performed using laser techniques that overcame some of the problems encountered with photogrammetry and enabled a complete 3D reconstruction of the Gothic apse. The investigation set the comparison between both techniques to evaluate its advantages and disadvantages from a wide point of view.

State of the art

\section{The techniques}

In the assessment of built heritage, the use of direct measurement techniques for architectural surveying requires a large number of resources. TLS has recently become more prominent because of its speed and simplicity (Bonora, Colombo, Marana, Mattioli, \& Marconi, 2005), (Lerones, Fernández, Gil, Gómez-García-Bermejo, \& Casanova, 2010), but photogrammetric techniques have a better cost-precision ratio, and they are therefore used more widely (P. Arias, Ordóñez, Lorenzo, \& Herraez, 2006), (Riveiro, Caamaño, Arias, \& Sanz, 2011).

The accuracy of those technologies has been extensively tested (Guarnieri, A., Vettore, A. and Remondino, 2004), (Alkan \& Karsidag, 2012), (Green, Bevan, \& Shapland, 2014), and they are therefore adequate methods for the accurate analysis of the geometry of buildings and are compatible with one another. In the specific case of surveying heritage constructions, many authors have tested the use of these techniques (Grussenmeyer, P., Landes, T., Voegtle, T., Ringle, 2008), (Kadobayashi, R., Kochi, N., Otani, H. and Furukawa, 2004), (Rizzi, Voltolini, Remondino, Girardi, \& Gonzo, 2007) and have shown their compatibility as well as the main differences that characterize them.

In this context, cathedrals are perhaps one of the most difficult cases, due to the complexity of the architectural forms and their large dimensions. Some works have set out partial surveys, including the Santiago de Compostela cathedral (Martínez, Ortiz, Gil, \& Rego, 2013) and the Milan cathedral (Fassi, Achille, \& Fregonese, 2011), as well as the totality of the interior space such as in the St. Johannis Cathedral in Meldorf (Sternberg, 2006). In those studies, good results were obtained.

The Terrestrial Laser Scanner (TLS) is a ranging technique that allows the quick and easy capture of the geometry of objects. It is a contactless, non-invasive surveying technique that allows the massive capture of geometric and radiometric data of a surface (Pesci, Bonali, Galli, \& Boschi, 2012). Its main limitations lie in the management of dense point clouds, the texturization of surfaces and the need to place the device in a stable position. In addition, cost is a very important limiting factor.

Additionally, photogrammetry is a remote sensing technique that is based on image correlation algorithms that identify the common points in photographs of the same object (Karara, 1989). Several techniques have evolved during the last decade. Close Range Photogrammetry (CRP) refers to the capture of objects with sizes that do not exceed $100 \mathrm{~m}$, where the camera is in a position close to the object (Cooper \& Robson, 2001). Points must be taken to locate the various photographs in the same Cartesian coordinate system (external orientation) and to process the photographs with specific software. The type of camera used, the 
texture of the surfaces and lighting conditions have a major influence in the mesh generation. The procedure allows 3D virtual reconstructions of the surveyed object to be obtained, which have many advantages for the documentation and conservation of cultural heritage (Yilmaz, Yakar, Gulec, \& Dulgerler, 2007).

Structure From Motion (SFM) is based on Dense Multi-View 3D reconstruction algorithms that generate 3D objects through a semiautomated process that can be performed with a low knowledge overhead from a user using appropriate software. Thus, it is becoming widespread because of its simplicity and ease of use in several disciplines, such as geoscience (Westoby, Brasington, Glasser, Hambrey, \& Reynolds, 2012), (Javernick, Brasington, \& Caruso, 2014), hydrology (Smith, Carrivick, Hooke, \& Kirkby, 2014) and especially in archaeology (De Reu et al., 2013), (McCarthy, 2014), (Hesse, 2015), because it enables the generation of low-cost 3D documentation of cultural heritage with great scientific value. Agisoft Photoscan 3D, Photomodeler, 123DCatch and pix4D are among the available software packages. It is possible to obtain high quality results for medium sized and large architectural objects, in the case of feature-rich surfaces under appropriate lighting conditions with large sets of images and the use of high performance computer system resources (Koutsoudis et al., 2014).

Thus, this technique was discarded for the study; due to the lighting conditions of the apse and the complexity of the architectural space, it would have required a large set of images that would have thereby increased the computational cost. The use of CLS allows a significant reduction in the amount of photographs that are needed to obtain a 3D reconstruction, but increases the work time in the office. Manual processes have the advantage of allowing greater control of the meshing process, and it is possible to correct errors in complex areas of the geometry of the vaults, such as the spring line of the ribs, where the image is very dark and it is difficult to completely avoid occlusions.

\section{The case study}

The apse of the Gothic Cathedral of Tortosa was built in the period 1374-1441 (Figure 1). The construction chronology has been precisely determined using cathedral construction accounts (Llibres d'Obra, Ll.o.), (Almuni, 2007). At the start of construction, a ring of nine radial chapels was built around the original Romanesque cathedral while the cathedral remained in use (Lluis i Ginovart, Fortuny-Anguera, Costa-Jover, \& de Sola-Morales-Serra, 2013). They were built sequentially and have a square floor plan with ribbed vaults. The second phase was the construction of nine vaulted ceilings in the ambulatory (1424-1435). Two are square, and seven are trapezoidal and were built symmetrically. Finally, the roof of the presbytery (1435-1441) was topped with a keystone weighing over 8 tonnes.

The theoretical framework that regulated the typological arrangement of the Tortosa Cathedral can be found in the main historical studies of gothic construction, including (Willis, 1842), (Viollet-le-Duc, 1854), (Ungewitter, 1892), (Babcock, 1893) or (Durm-(et.al), 1901). The Cathedral style is Meridional Gothic, which is characterized by a small difference between the height of central and the lateral naves, flat profile of the roof, small windows, and the suppression of ornamentation.

The layout of the gothic project was governed by proportional rules that established the main dimensions of the construction. Thus, the section has a modular relation that is linked to the floor plan measure. A detailed review of the theoretical framework of Gothic design related to the cathedral of Tortosa and its layout can be found in (Lluis i Ginovart \& Costa, 2014). 

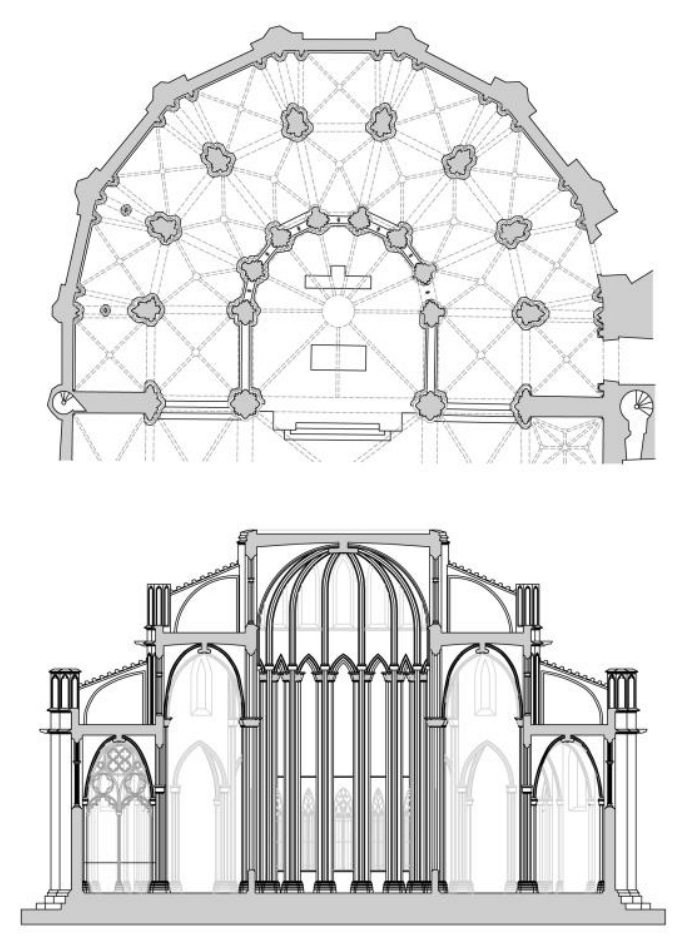

In typological terms, the vaults of the heptagonal apse of Tortosa are located at three different heights. In addition, the radial chapels are connected visually, with the traditional separation wall being replaced by a pillar on the ambulatory. The elimination of the wall between the chapels had been tentatively attempted at Santa Maria de la Aurora in Manresa (1328), with a cross-section ad triangulum of 8/7. This wall was completely eliminated in Tortosa around 1377, establishing a lower cross-section ratio of $9 / 5$. This structural issue appeared years later in the debate over the Cathedral of Milan (1392) (Valentini, 1990).

The unit of measurement of the cathedral (1347) found in the Ll.o. is the cana (Almuni, 1991), which is equivalent to 8 palms. A palm is 12 fingers. A comparison of the documents that standardized the Tortosa cana with the one used in Barcelona (24-VII-1593) proves that the Tortosa cana used in the cathedral measures $1,858 \mathrm{~cm}$ and the palm measures $23.23 \mathrm{~cm}$.

\section{Methodology}

The aim of this investigation was to evaluate the application of the selected techniques in the specific assessment case, which was the complex interior space of a Gothic apse. A meticulous analysis of the two techniques' precisions and accuracies was not attempted. As previously discussed, other researchers have undertaken such analyses. Thus, on one hand, the purpose of the comparison is a general assessment of the geometric differences between the three-dimensional models. These are the formal distortions caused by the system that is used. On the other hand, the ratio of the resources utilized in the execution (temporary and technical) to the obtained results will be evaluated.

The economic resources were not considered, as it is very difficult to establish a comparative framework in monetary terms. The market offers multiple choices; the variety of devices and the access through purchase or rental allow an adaptation in each particular case. In general terms, the use of a TLS will require a higher economic investment, although with adequate means it is possible to reduce management time and post-production, compensating costs. A brief description of the process that was utilized and the resources that were used is presented below.

\section{Close Range Photogrammetry}

The 3D model was obtained using a combination of a Total Station, Topcon Imaging Station 203 (with an accuracy of $0.2 \mathrm{~mm} / 1 \mathrm{~mm}$ $\pm(5 \mathrm{~mm}), 1.3 \mathrm{MP}$ cameras with frame rates of 1-10 fps, Scan Max $20 \mathrm{pts} / \mathrm{sec}$ ) and a Nikon D7000+Tokina 12-24 mm camera. The camera was calibrated using Image Master calibration software by taking several camera shots in a calibration grid in different positions and orientations. The 3D modelling was generated for surfaces using stereo pairs of photographs oriented by means of topographic points, which are called control points.

Due to their sizes and shapes, it was necessary to capture partial images of the vaults and identify common points for the outward orientation based on a Cartesian system, based on the mathematical principles of photogrammetry (Riveiro, Solla, de Arteaga, Arias, \& Morer, 2013). The topography support of the apse was obtained using 221 points, with five positioning stations. Singular points of the carved reliefs in the keystones of the vault were used as a reference to record them in a single system of coordinates with an accuracy of $10 \mathrm{~mm}$. 
At least 2 photographs were taken for each vault, with a very high percentage of overlap. The typical parameters that are used for capturing images were taken into account (Pedro Arias, Carlos Caamaño, Lorenzo, \& Armesto, 2007). However, the changing light conditions and the different exposures of the surfaces required image preprocessing and texture equalization.

The 3D model (Figure 2) was generated with Image Master using surfaces from stereo pairs of photographs oriented by means of the control points. The surfaces consisted of a TIN (triangulated irregular network), which incorporated the real textures of the masonry by mapping with the same stereo pairs of photographs. The proposed mesh pass was $30 \mathrm{~mm}$, using a total of 43 photographs.

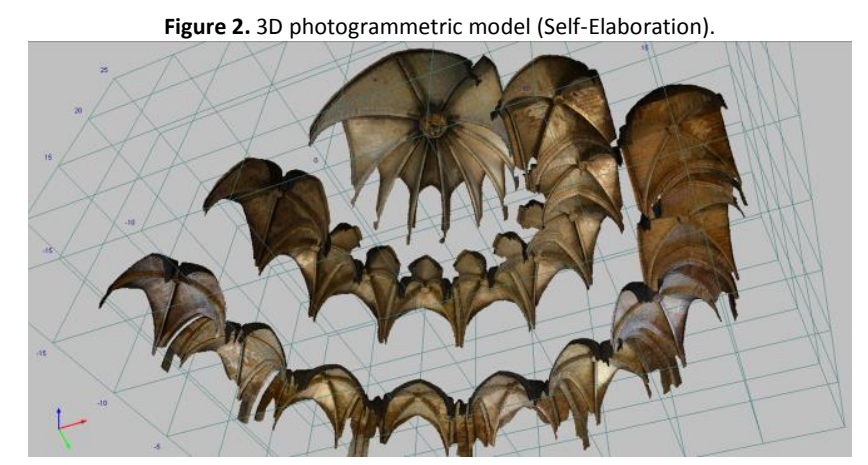

\section{Terrestrial Laser-Scanner}

A C10 Leica laser scanner, which is a compact device for mid-range measurements that uses the time-of-flight principle, was used. With a complete field of vision (360 horizontal, 270 vertical), high speed scanning was possible, with an accuracy of $6 \mathrm{~mm}$ per point up to a range of $50 \mathrm{~m}$. Images were captured at each station to specify the colour of the points using a Canon EOS 60D external camera with a resolution of 18 megapixels and a Sigma $8 \mathrm{~mm}$ wide-angle lens, which was controlled directly by the scanner.

The complexity of the architectural layout required a large number of stations to avoid occlusions in the model. 32 intermediate stations were established, using a medium density scanning mesh (the lecture mesh was set at 1 point per lineal $\mathrm{cm}$ at $10 \mathrm{~m}$ of distance), with 25 artificial targets strategically distributed around the entire space to reference each position within the same coordinate system.

The software package Cyclone, which automatically registered the reference points of each station and placed the point clouds in the same local coordinate system, was used to process the point cloud. In a second stage, the program 3DReshaper was used to generate the 3D mesh of the model (Figure 3) from the selected points. The mesh density was adjusted at an average triangle size of $2.5 \mathrm{~cm}$, which was later refined.

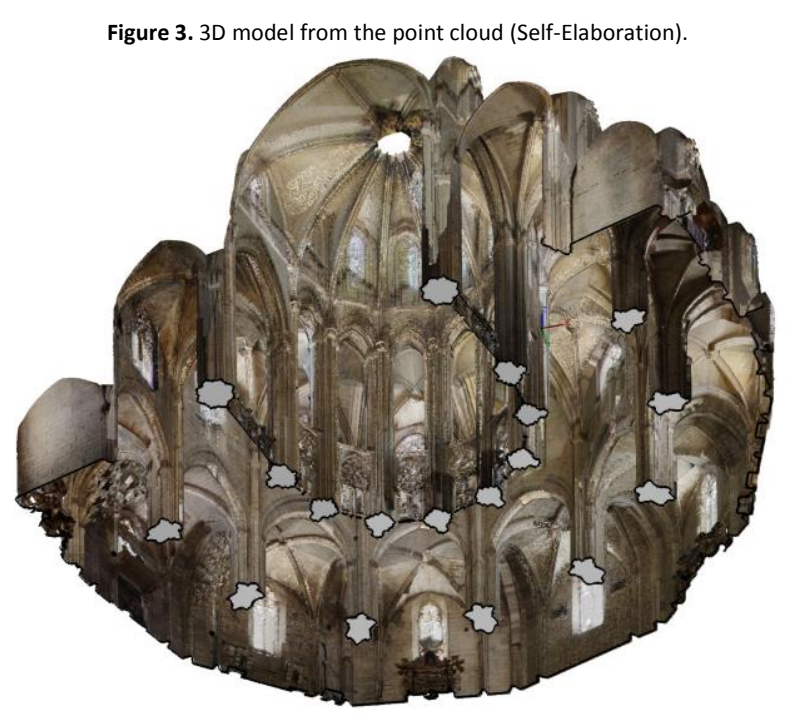




\section{Comparison of models}

A 3D model of the object with a known scale and coordinate system $(x, y, z)$ was obtained using each technique. The TLS enabled us to obtain a complete model of the apse, while the CLS was limited to the vaulted surface. Thus the comparative analysis was performed on that surface. Two different methodologies were used to compare the two models:

- A general comparison between both 3D models.

- A discreet comparison between common points.

The general comparison between the two models was performed using 3DReshaper software, which allowed us to automatically generate a mapping of the different geometries between both models (Figure 4). A reference mesh (in this case the TLS mesh) was defined, and it was compared with another (CLR). The program calculated the distance of the normal component of the triangular surfaces. The program generated a mapping according to the relative distances between the two objects and established ranges (and percentages) according to the resulting values.

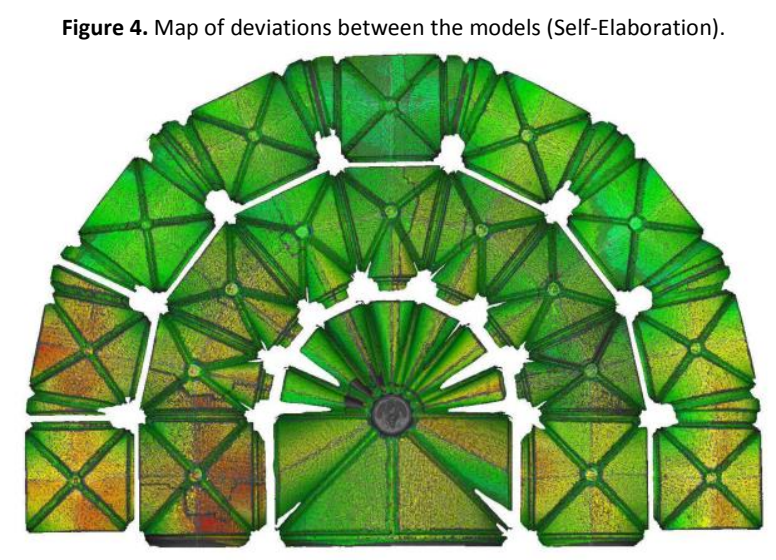

This comparison illustrates the difficulty of inserting the models in the same coordinate system because each mesh was generated with a different technique and software system. Common points were identified in the keystones of the vaults and were used as control points to integrate both of the models into the same Cartesian coordinate system.

For the detailed comparison of the points, it was possible to parameterize the coordinates that define the geometry of the vaults from the 3D mesh. The desired points were identified through cross-section plans and geometric transformations to set them within the same 2D system $(x, y)$. (Figure 5 ). Thus, pairs of sections were defined using the axial coordinates for both models, and the coordinates that were obtained were entered into an Excel spreadsheet for statistical analysis. The start and end coordinates of the upper edge of the severies and the heights of each keystone were analysed. The numerical values are listed to undertake a comparative study of the deviations in each of the vaults.

Figure 5. Sections of the TLS model (up) and CRP (down) (Self-Elaboration).

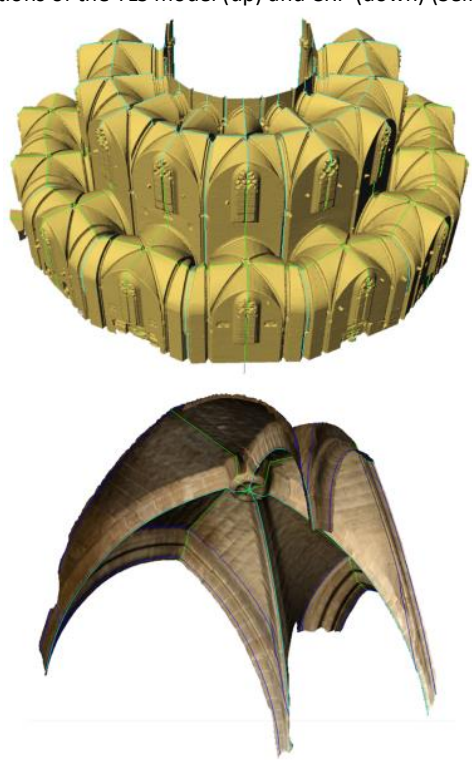


From a qualitative point of view, in general terms the vaults that are located in the lateral extremes of the photogrammetric model tend to be higher than those in the TLS model, while the central vaults are lower and closer. The greater differences are located on the left side of the models (according to the orientation shown in (Figure 4). If the differences are analysed individually on each vault, the greater variations are located around their main axes. Thus, there is a loss of proportionality in the 3D reconstruction.

In quantitative terms, a total of 506056 points were compared using 3D Reshaper. It measures the distance between a point of the photogrammetric mesh and the nearest point of the mesh obtained by the laser scanner. The percentage for each distance range is summarised in (Figure 6). The maximum and minimum values are between -0.72 and $0.91 \mathrm{~cm}$ ( 1 and 2 points, respectively). They were caused by background noise, according to the dispersion of the values and the small number of points.

Figure 6. Histogram of the comparison (Self-Elaboration).

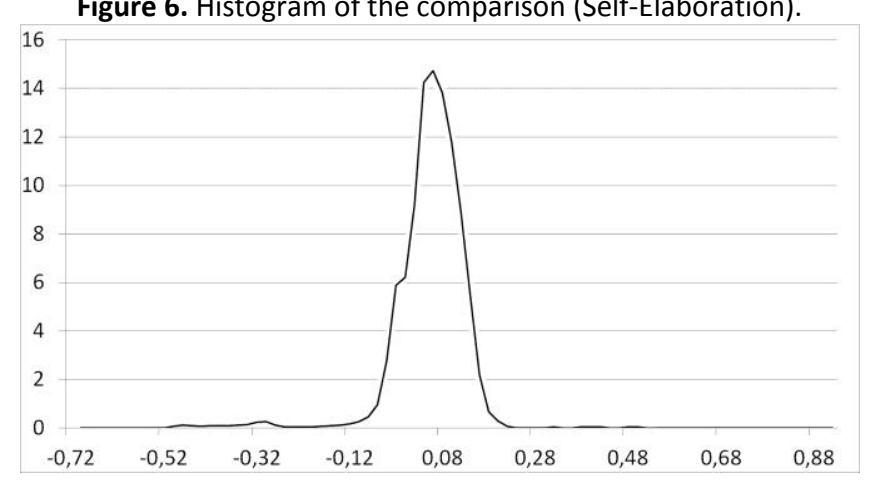

Otherwise, 131068 points (25.9\%) are in a range of $2 \mathrm{~cm}$, and 177227 (35\%) have a distance between 2 and $4 \mathrm{~cm}$. Both the mode and the average value are $4 \mathrm{~cm}$, which defines the standard error of the mean. If we ponder this result, suppressing the bottom left of the vaulted area where there are major discrepancies, the value of the standard error of the mean is greater than $2 \mathrm{~cm}$.

In the discrete analysis, the coordinates $(x, y)$ of 108 points were identified in the vaults of both models, and their heights were compared (Table 1). In the table, $\mathrm{Ha}$ is the centre of the keystone, $\mathrm{Hb}$ is the intersection between the ribs and the keystone, and $(H c, H d)$ are the extreme points of the main axes $(S I, S I I)$ of the vaults. The mean distance between corresponding points is $2.1 \mathrm{~cm}$, and the extreme distances range from 0 (maximum correspondence) to $9.10 \mathrm{~cm}$. Also the range of distances is shown in Figure 7; there are very few values that exceed a range of $0.5 \mathrm{~cm}-5 \mathrm{~cm}$.

Table 1. Discrete comparison between models. Extreme values (cm) (Self-Elaboration).

\begin{tabular}{|c|c|c|c|c|c|c|c|}
\hline & & $\mathrm{Ha}$ & $\mathrm{Hb}$ & $\mathrm{Hc}(\mathrm{SI})$ & $\mathrm{Hd}(\mathrm{SII})$ & $\mathrm{Hc}(\mathrm{SI})$ & $\mathrm{Hd}(\mathrm{SII})$ \\
\hline \multirow{2}{*}{ Chapels } & Max & 0,055 & 0,048 & 0,074 & 0,065 & 0,061 & 0,070 \\
\hline & Min & 0,005 & 0,014 & 0,005 & 0,001 & 0,002 & 0,012 \\
\hline \multirow{3}{*}{ Ambulatory } & Max & 0,031 & 0,032 & 0,084 & 0,091 & 0,066 & 0,044 \\
\hline & Min & 0,003 & 0,003 & 0,005 & 0,014 & 0,000 & 0,003 \\
\hline & Max & 0,055 & 0,048 & 0,084 & 0,091 & 0,066 & 0,070 \\
\hline \multirow[t]{2}{*}{ General } & Min & 0,003 & 0,003 & 0,005 & 0,001 & 0,000 & 0,003 \\
\hline & MIN & 0,018 & 0,023 & 0,040 & 0,039 & 0,032 & 0,028 \\
\hline
\end{tabular}

Table 2. Distances between the surveyed points of both models $(\mathrm{cm})$ (Self-Elaboration).

\begin{tabular}{ccc} 
Dist. $(\mathrm{cm})$ & no & $\%$ \\
\hline 0,5 & 14 & 13 \\
1 & 22 & 20 \\
2 & 52 & 48 \\
3 & 69 & 64 \\
4 & 84 & 78 \\
5 & 95 & 88
\end{tabular}

The overall accuracy of the two techniques is similar, although some coordinates occasionally differ considerably. The TLS very rarely produced errors (apart from occasional noise, which was usually refined during post-processing). However, the photogrammetry was strongly influenced by the quality of the images and the texture of the surfaces. Some isolated distortions in 
the model are therefore likely to appear during the capture of an interior space under adverse lighting conditions (e.g., in dark areas and under changing light) and complex forms. In addition, the model obtained presents a loss of proportionality in some parts of the mesh. Thus, the TLS may be more appropriate in that sense to perform the survey.

Even though differences were observed in the comparative analysis, the deviation values are small in architectonic terms and in proportion with the studied object. For data collection, the TLS system is highly reliable, quick, and simple. In contrast, the technical and consequent economic resources that are needed are greater than those required by CLR, therefore CLR is still a good low-cost alternative, despite the problems that have been described.

About resources, time and technical means can be differentiated. The technical resources that were used for CLR were a camera and a topographic station, whereas for the TLS only the laser device was required. Moreover, both methodologies required specific software and computers to process the data. In this case, TLS needed the most powerful hardware.

Considering time, the fieldwork for each case took approximately 16 hours. The amount of registered data in the case of TLS was much superior to that of the CRP, which allowed the geometric definition of complex elements that would have been very complicated to obtain otherwise. On the contrary, the textures that were obtained with CRP have better quality than the TLS derived textures. It would be possible to combine the geometrical data of the laser with the photogrammetry textures. The photogrammetry post-processing took 10 working days, whereas in the TLS it took 5 , including the calculation time. In this case, the laser was much more efficient, although the hardware required more processing power.

\section{Conclusions}

The comparison between the two methods used in the survey has primarily allowed data validation and, in addition, assessments of their accuracies and suitabilities, in the particular case of a complex masonry structure.

The light conditions and the complexity of the vaulted apse complicated the use of photogrammetry, and the TLS performed best for the fieldwork. Furthermore, the use of the TLS enabled the complete geometry of the space to be obtained, whereas the photogrammetry was limited to the survey of the vaults of the apse (the survey of pillars and walls would have significantly increased the time required).

A new highly detailed and accurate survey has been obtained using massive data capture techniques. This documentation is priceless because it paves a path for new multidisciplinary investigations and has revealed new data regarding the construction history of the apse that were not recorded in the primary sources. This information is fundamental for understanding and preserving the building. Moreover, the resulting conclusions will allow an optimization of the techniques to perform a complete virtual reconstruction of the cathedral.

\section{References}

Alkan, R. M., \& Karsidag, G. (2012). Analysis of The Accuracy of Terrestrial Laser Scanning Measurements, (May 2012), 6-10.

Al-kheder, S., Al-shawabkeh, Y., \& Haala, N. (2009). Developing a documentation system for desert palaces in Jordan using 3D laser scanning and digital photogrammetry. Journal of Archaeological Science, 36(2), 537-546. http://doi.org/10.1016/j.jas.2008.10.009

Almuni, V. (1991). L'Obra de la Seu de Tortosa (1345-1441). Tortosa: Cooperativa Gràfica Dertosense.

Almuni, V. (2007). La catedral de Tortosa als segles del gótic. Barcelona: Fundació Noguera, Col-lecció Estudis.

Arias, P., Carlos Caamaño, J., Lorenzo, H., \& Armesto, J. (2007). 3D Modeling and Section Properties of Ancient Irregular Timber Structures by Means of Digital Photogrammetry. Computer-Aided Civil and Infrastructure Engineering, 22(8), 597-611. http://doi.org/10.1111/j.14678667.2007.00512.x

Arias, P., Ordóñez, C., Lorenzo, H., \& Herraez, J. (2006). Methods for documenting historical agro-industrial buildings: a comparative study and a simple photogrammetric method. Journal of Cultural Heritage, 7(4), 350-354. http://doi.org/10.1016/j.culher.2006.09.002

Babcock, C. (1893). Vaults, by Professor Charles Babcok. Boston: Cornell University.

Bonora, V., Colombo, L., Marana, B., Mattioli, V., \& Marconi, V. (2005). Laser technology for cross-section survey in ancient buildings: a study for S.M. Maggiore in Bergamo. Proceedings of the CIPA 2005 XX.

Cooper, M., \& Robson, S. (2001). Theory of Close Range Photogrammetry. (A. K.B., Ed.) (Close Rang, pp. 9-51). Caithness, Scotland: Whittles Publishing.

De Reu, J., Plets, G., Verhoeven, G., De Smedt, P., Bats, M., Cherretté, B., ... De Clercq, W. (2013). Towards a three-dimensional cost-effective registration of the archaeological heritage. Journal of Archaeological Science, 4O(2), 1108-1121. http://doi.org/10.1016/j.jas.2012.08.040

Durm-(et.al). (1901). Handbuch der Architektur. Dritter Teil: Die Hochbau konstruktionen. (2b.H.3.b Bergsträsser, Arnold, Ed.) (pp. 163-192). Stutgart: Raumbegrenzende Konstruktionen.

Fassi, F., Achille, C., \& Fregonese, L. (2011). Surveying and modelling the main spire of Milan Cathedral using multiple data sources. The Photogrammetric Record, 26(136), 462-487. http://doi.org/10.1111/j.1477-9730.2011.00658.x

Green, S., Bevan, A., \& Shapland, M. (2014). A comparative assessment of structure from motion methods for archaeological research. Journal of Archaeological Science, 46(1), 173-181. http://doi.org/10.1016/j.jas.2014.02.030

Grussenmeyer, P., Landes, T., Voegtle, T., Ringle, K. (2008). Comparison methods of terrestrial laser scanning, photogrammetry and tacheometry data for recording of cultural heritage buildings. International Archives of Photogrammetry, Remote Sensing and Spatial Information Sciences, 37(B5), 213-218.

Guarnieri, A., Vettore, A. and Remondino, F. (2004). Photogrammetry and ground-based laser scanning: assessment of metric accuracy of the 3D model of Pozzoveggiani Church. In Working Week, The Olympic Spirit in Surveying. Athens.

Hesse, R. (2015). Combining Structure-from-Motion with high and intermediate resolution satellite images to document threats to archaeological heritage in arid environments. Journal of Cultural Heritage, 16(2), 192-201. http://doi.org/10.1016/j.culher.2014.04.003 
Javernick, L., Brasington, J., \& Caruso, B. (2014). Modeling the topography of shallow braided rivers using Structure-from-Motion photogrammetry. Geomorphology, 213, 166-182. http://doi.org/10.1016/j.geomorph.2014.01.006

Kadobayashi, R., Kochi, N., Otani, H. and Furukawa, R. (2004). Comparison and evaluation of laser scanning and photogrammetry and their combined use for digital recording of cultural heritage. International Archives of Photogrammetry.

Karara, H. M. (1989). Non Topographic Photogrammetry. ASPRS.

Koutsoudis, A., Vidmar, B., loannakis, G., Arnaoutoglou, F., Pavlidis, G., \& Chamzas, C. (2014). Multi-image 3D reconstruction data evaluation. Journal of Cultural Heritage, 15(1), 73-79. http://doi.org/10.1016/j.culher.2012.12.003

Lerones, P. M., Fernández, J. L., Gil, Á. M., Gómez-García-Bermejo, J., \& Casanova, E. Z. (2010). A practical approach to making accurate 3D layouts of interesting cultural heritage sites through digital models. Journal of Cultural Heritage, 11(1), 1-9. http://doi.org/10.1016/j.culher.2009.02.007

Lluis i Ginovart, J., \& Costa, A. (2014). “Design and medieval construction: the case of Tortosa catedral (1345-1441)." Construction History, 29 No. 1, $1-24$.

Lluis i Ginovart, J., Fortuny-Anguera, G., Costa-Jover, A., \& de Sola-Morales-Serra, P. (2013). Gothic Construction and the Traça of a Heptagonal Apse: The Problem of the Heptagon. Nexus Network Journal, 15(2), 325-348. http://doi.org/10.1007/s00004-013-0152-x

Lluis i Ginovart, J., \& Llorca, A. (2000). Pla Director Sancta Maria Dertosae. Tortosa. (B. de Tortosa, Ed.). Departament Cultura Generalitat de Catalunya.

Lluis i Ginovart, J., Toldrà, J. M., Costa, A., \& Coll, S. (2014). Close Range Photogrammetry and Constructive Characterization of Masonry Gothic Vaults. Revista de La Construcción, 13(1), 47-55.

Martínez, S., Ortiz, J., Gil, M. L., \& Rego, M. T. (2013). Recording Complex Structures Using Close Range Photogrammetry: The Cathedral of Santiago De Compostela. The Photogrammetric Record, 28(144), 375-395. http://doi.org/10.1111/phor.12040

McCarthy, J. (2014). Multi-image photogrammetry as a practical tool for cultural heritage survey and community engagement. Journal of Archaeological Science, 43(1), 175-185. http://doi.org/10.1016/j.jas.2014.01.010

Morán Proaño, M., Álvarez Rodríguez, O. (2012). Investigación de las vibraciones por tráfico en las construcciones patrimoniales de adobe. Revista de La Construcción, 11(2), 39-53.

Núñez, M. a., Buill, F., Regot, J., \& De Mesa, a. (2012). Levantamiento arquitectónico de la Puerta de Antioquía (Alepo). Informes de La Construcción, 64(528), 487-496. http://doi.org/10.3989/ic.11.090

Pavlidis, G., Koutsoudis, A., Fotis, A., Vassilios, T., \& Christodoulos, C. (2007). Methods for 3D digitization of Cultural Heritage. Journal of Cultural Heritage, 8(1), 93-98. http://doi.org/10.1016/j.culher.2006.10.007

Pesci, A., Bonali, E., Galli, C., \& Boschi, E. (2012). Laser scanning and digital imaging for the investigation of an ancient building: Palazzo d'Accursio study case (Bologna, Italy). Journal of Cultural Heritage, 13(2), 215-220. http://doi.org/10.1016/j.culher.2011.09.004

Riveiro, B., Caamaño, J. C., Arias, P., \& Sanz, E. (2011). Photogrammetric 3D modelling and mechanical analysis of masonry arches: An approach based on a discontinuous model of voussoirs. Automation in Construction, 20(4), 380-388. http://doi.org/10.1016/j.autcon.2010.11.008

Riveiro, B., Solla, M., de Arteaga, I., Arias, P., \& Morer, P. (2013). A novel approach to evaluate masonry arch stability on the basis of limit analysis theory and non-destructive geometric characterization. Automation in Construction, 31, 140-148. http://doi.org/10.1016/j.autcon.2012.11.035

Rizzi, A., Voltolini, F., Remondino, F., Girardi, S., \& Gonzo, L. (2007). Optical measurement techniques for the digital preservation, documentation and analysis of cultural heritage. 8th Conference on Optical 3D Measurement Techniques, 16-24.

Smith, M. W., Carrivick, J. L., Hooke, J., \& Kirkby, M. J. (2014). Reconstructing flash flood magnitudes using "Structure-from-Motion": A rapid assessment tool. Journal of Hydrology, 519(PB), 1914-1927. http://doi.org/10.1016/j.jhydrol.2014.09.078

Sternberg, H. (2006). Deformation measurements at historical buildings with terrestrial laserscanners, XXXVI(September), 303-308.

UNESCO. (1964). International charter for the conservation and restoration of Monuments and Sites (The Venice Charter). In 2nd International Congress of Architects and Technicians of Historic Monuments. May 25-31.

UNESCO. (1972). Convention Concerning the Protection of the World Cultural and Natural Heritage. Paris. World Heritage Centre. Retrieved from http://whc.unesco.org/en/conventiontext/

UNESCO. (2003). IMCOMOS, Principles for the Analysis, Conservation and Structural Restoration of Architectural Heritage.

Ungewitter, G. (1892). Lehrbuch der Gotischen Konstruktionen (Weigel Nac, Vol. 1, pp. 29-67). Leipzig.

Valentini, J. (1990). Il duomo de Milano. Una disputa medievales sul modelo del Tempio. Nuove Edizioni Duomo, 66.

Viollet-le-Duc, E. E. (1854). Dictionnaire raisonné de l'architecture française du Xle au XVle siècle. (p. 10 vol). Paris: B. Bance (A. Morel).

Westoby, M. J., Brasington, J., Glasser, N. F., Hambrey, M. J., \& Reynolds, J. M. (2012). "Structure-from-Motion" photogrammetry: A low-cost, effective tool for geoscience applications. Geomorphology, 179, 300-314. http://doi.org/10.1016/j.geomorph.2012.08.021

Willis, R. (1842). On the construction of the vaults of the middle ages. (Longman, Ed.) (Royal Inst, pp. 17-31). London.

Yilmaz, H. M., Yakar, M., Gulec, S. a., \& Dulgerler, O. N. (2007). Importance of digital close-range photogrammetry in documentation of cultural heritage. Journal of Cultural Heritage, 8(4), 428-433. http://doi.org/10.1016/j.culher.2007.07.004 